\title{
Ocular surface degenerative diseases studies in an isolated region of Argentine Patagonia
}

\author{
María Fernanda Suárez ${ }^{1}$, Nicolás Crim ${ }^{2,3}$, Leandro Javier Correa ${ }^{2}$, Juan Pablo Maccio ${ }^{2}$, Erna Gertrudis Knoll ${ }^{2}$, María del Carmen Piqueras ${ }^{4}$ \\ Andrés Lisker-Cervantes ${ }^{3}$, Sanjoy K Bhattacharya ${ }^{4}$ and Horacio Marcelo Serra ${ }^{1 *}$ \\ ${ }^{1}$ CIBICI, Department of Clinical Biochemistry, Faculty of Chemical Sciences, Universidad Nacional de Córdoba, Córdoba, Argentina \\ ${ }^{2}$ Department of Ophthalmology, University Clinic Reina Fabiola, Universidad Católica de Córdoba, Argentina \\ ${ }^{3}$ Asociación Para Evitar la Ceguera, "Hospital Dr. Luis Sánchez Bulnes”, IAP. Mexico City, México \\ ${ }^{4}$ Bascom Palmer Eye Institute, (McKnight Bldg.) University of Miami. Miami, FL, USA
}

\begin{abstract}
Aim: The aim of this study was to investigate the prevalence of Environmental proteinaceous corneal degeneration (EPCD), pinguecula and pterygium and any association among them, and to perform lipidomic studies in some samples of EPCD and pterygium.

Materials and methods: It was a transversal/observational and analytical study; the sample was consecutive non-probabilistic. All patients examined resided all their lives in the department El Cuy (Río Negro). Corneal epithelium and conjunctiva tissue samples were taken to perform mass spectrometric lipidomic studies.

Results: One hundred and fifty-nine patients were studied (52.83\% male and $47.17 \%$ female). The prevalence of ophthalmoheliosis was: pinguecula $32.1 \%$, EPCD $28.9 \%$, and pterygium 13.2\%. A statistically significant association was found between EPCD and male patients (21.4\% vs $7.5 \%)$ $(\mathrm{p}<0.05)$. There was association between EPCD with pinguecula and with pterygium, both more frequent in males $(\mathrm{p}<0.05)$. Lipidomic studies in EPCD showed a decrease in the concentration of phospholipids in affected areas (15 times less). In pterygium, there was an increase in the concentration of phospholipids (6.67 times more).

Conclusion: Our investigation shows important prevalence of EPCD, pinguecula and pterygium in individuals that live at El Cuy (Argentine Patagonia). As far as we know, this is the first work in the world that shows coexistences between these three ophthalmoheliosis. The decrease concentration of phospholipids in EPCD affected areas could be due to lipid peroxidation, as a consequence of oxidative stress. On the other hand, higher levels of PC and PS in pterygium samples could be explained by the increase in proliferation and angiogenesis.
\end{abstract}

\section{Introduction}

The term helioses derives from the Greek root "hēlíosis" which means excessive exposure to sunlight, a mixture of radiation with wavelengths ranging from $200 \mathrm{~nm}$ to $4000 \mathrm{~nm}$, which comprises ultraviolet radiation (UVR), visible light and infrared light [1]. UVR has been found to reach diverse ocular components and is strongly absorbed by the anterior structures of the eye [2]. The cornea absorbs UVR differentially, based on the incident wavelength. More than $90 \%$ of UVR-C and UVR-B are absorbed by this ocular structure, as well as $60 \%$ of UVR-A, [3] while the rest of the UVR-A is absorbed by the crystalline, with less than $1 \%$ reaching the retina [4]. Absorbed UVR is an important source of stress for the ocular surface through direct photo-oxidation (or type I). Also, indirect photo-oxidation (type II) can occur and produce reactive oxygen species (ROS), which damage protein, lipids and cellular DNA [5-8].

There are different eye diseases associated with harmful exposure to UV light without adequate eye protection, known as ophthalmoheliosis. Among them, we can mention three degenerative diseases of the ocular surface: climatic droplet keratopathy (CDK), pinguecula and pterygium. These diseases with still elusive etiology but with possibly multifactorial origin are frequently found in rural environments with high insolation.

CDK is a rare acquired, bilateral degenerative disease of the cornea, which is highly prevalent in certain rural communities exposed to harsh weather conditions, that evolves through three different degrees of severity, leading to severe visual compromise as the result of corneal opacification [9]. As CDK is not specifically associated to weather, but to certain environmental conditions, we recently proposed to name it "Environmental Proteinaceous Corneal Degeneration" (EPCD) [10].

${ }^{\star}$ Correspondence to: Horacio M. Serra, CIBICI, Faculty of Chemical Sciences, National University of Córdoba, Haya de la Torre esquina Medina Allende, PC 5000, Córdoba, Argentina; Tel: +54 351 5353851; Fax: +54 351 535-3850; E-mail: hserra@fcq.unc.edu.ar

Key words: environmental proteinaceous corneal degeneration, pterygium, pinguecula, lipids, Argentina

Received: January 08, 2019; Accepted: January 21, 2019; Published: January 23, 2019 
Current revisions on advances of molecular mechanisms involved in EPCD and pterygium have been published by Serra [11] and by Cardenas-Cantu [12].

Pinguecula is a yellowish globular or flat benign conjunctival growth, near the corneal limbus in the interpalpebral fissure, produced by the alteration of the underlying connective tissue [13-14]. Although there is some evidence of its development upon exposure to sunlight, [15] its pathogenesis is ignored. In some patients it seems to be a precursor of a pterygium [16].

Even though the prevalence of one or more of these distinct ophthalmoheliosis have been studied in different parts of the world, as far as we know the co-existence of these degenerative diseases of the ocular surface has not yet been studied.

The purpose of our study was to investigate the prevalence of EPCD, pinguecula and pterygium and possible associations among them, if any, in individuals of this region of Argentina. As well, we performed lipidomic studies in surgical samples of some patients with EPCD and pterygium in order to explore the possible role of certain lipids in the etiopathogenesis of these diseases.

\section{Materials and methods}

\section{Study design and participants}

The chosen sample for the study was non-probabilistic consecutive, transversal/observational and analytical study. We analyzed the clinical records of patients who only had pinguecula or only pterygium of up to 10 years previous to our collection. Patients were examined by their ophthalmology specialist (at ages $\geq 29$ years), who lived all their lives in El Cuy department, Province of Río Negro, Argentina ( $n=159)$, who agreed to participate in the study after signing an informed consent.

The protocol for this study was approved by the Institutional Committee of Ethics and Investigation in Health of the University Clinic Reina Fabiola, and the Council for Ethical Research Evaluation of the government of the Province of Cordoba, Argentina, and registered in the Provincial Registry for Investigation in Health, Province of Cordoba. All studies adhered to Helsinki declaration.

\section{Geographical, climatic and demographic characteristics of the region}

As depicted in figure 1, El Cuy department is found in the Province of Rio Negro, 750 meters above sea level between at $38^{\circ}$ $56^{\prime}-40^{\circ} 25^{\prime}$ of south latitude and $67^{\circ} 54^{\prime}-69^{\circ} 04^{\prime}$ west longitude. It is $280 \mathrm{~km}$ from the border with Chile and $300 \mathrm{~km}$ away from the Atlantic Ocean. This region of $11,281 \mathrm{~km}^{2}$ has a semi-arid weather (Bwk, Köppen classification ) (http://koeppen-geiger.vu-wien. ac.at/shifts.htm) low shrubbery, annual rainfall lower than $190 \mathrm{~mm}$, constant strong winds, warm summers and cold winters, and great thermal amplitude between day and night. The annual range of temperature is between $4.6^{\circ} \mathrm{C}$ and $18.2^{\circ} \mathrm{C}$. According to the last census, the population density is $0.2 / \mathrm{km}^{2}$.

\section{Determination of density of the ozone layer}

Media Concentration of the ozone $\left(\mathrm{O}_{3}\right)$ column was obtained using $\mathrm{O}_{3}$ values from the website of NASA, USA: Total Ozone Mapping Spectrometer (TOMS-NASA), as previously shown [17]. Four samplings were obtained on the following dates: March 21, June 21 , September 21 and December 21 to determine the yearly average. The density of the ozone layer was measured in Dobson units $(\mathrm{Du})$ and the values vary depending on the altitude and latitude, considering normal values the range between $230 \mathrm{Du}-300 \mathrm{Du}$. A hole in the ozone layer is considered when the density of the layer in a specific region is under $200 \mathrm{Du}$.

\section{Ophthalmologic examination}

All subjects underwent an ophthalmologic exam that included visual acuity testing with Snellen chart, or Landolt/E rings for illiterate individuals. Additionally, a detailed slit-lamp examination of the anterior segment (conjunctiva, cornea, anterior camera and iris).

\section{Lifestyle}

Questions related to diet, work activity and the use of eye protection (sunglasses, hats) during lifetime were asked to all patients.

\section{Corneal and conjunctival specimens}

In patients with advanced degrees of $\operatorname{EPCD}(n=3)$ who were undergoing cataract surgery, cornea samples were obtained. Previous to the cataract surgery, and under local anesthetic, a scarification with a crescent blade of $1 \mathrm{~mm}^{2}$ was performed in the affected areas by EPCD (interpalpebral area of the cornea) and as control samples in areas not affected by this pathology (corneal epithelium covered by the eyelids), scarifying up to the basal membrane of the cornea.

Conjunctival tissue from individuals affected by pterygia $(n=3)$ were collected during the corresponding surgery, as a surgical incision was needed. As control samples, areas not affected by the pathology were obtained. All samples were conserved at $-80^{\circ} \mathrm{C}$ in vials until use.

\section{Lipid identification by mass spectrometry}

Corneal epithelial cells of the conjunctival tissue were subject to lipid extraction using Bligh and Dyer slightly modified method [18]. The concentration of protein contained in the corresponding aqueous phase (from lipid extraction) was determined using Bradford method (Bio-Rad, Hercules, CA) with purified BSA as standard. All extractions and subsequent manipulation of samples was done using glass vials. Samples were kept at $-80^{\circ} \mathrm{C}$ until use.

Lipids identification and quantification were done as previously described [19]. Briefly, lipid samples were re-suspended in acetonitrile -isopropanol (1:1) LC-MS grade and later subjected to direct infusion using TriversaNanomate (Advion Inc., Ithaca, NY) into a triple quadrupole mass spectrometer (TSQ Quantum Access Max; Thermo Fisher Scientific, Pittsburgh, PA) operated using Xcalibur 2.3 software. The mass spectrometer was operated in positive ion mode and parent ion scan (PIS) for phosphatidylcholine (PC) species, setting a collision energy of $35 \mathrm{~V}$ for a product ion of $\mathrm{m} / \mathrm{z} 184$. For phosphatidylserine (PS) species, it was operated in negative ion mode and neutral loss scan (NLS), for a neutral loss mass of $m / z 87.100$ with a $24 \mathrm{~V}$ collision energy. The addition of $0.1 \%$ of formic acid is used for the analysis of lipids in ion positive mode to favor ionization. Specific class lipids were quantified using specific lipid standards: 1,2-ditridecanoil-snglicero-3-fosfocholine and 1,2-dioleoil-sn-glicero-3-fosfo-L-serine. The standards were purchased from Avanti Polar Lipids, Albaster, AL, USA.

The identification and quantification were done using MZmine 2.9 program. Lipid concentrations were normalized to the determined amount of protein in the corresponding aqueous phase as previously described. Representative spectrum of each sample was carefully and manually inspected and selected by two independent observers from the 5 collected spectrums, with and without internal standard (10 spectrums in total) and used for posterior analysis. 


\section{Statistical analysis}

Statistical studies of value comparison were made using Student $\chi^{2}$ Pearson and ANOVA tests. The level of statistical significance was set at $\mathrm{p} \leq 0.05$.

\section{Results}

All participants in the study had always lived in the same area previously described (Figure 1). Of 159 individuals, 52.83\% (84) were male and $47.17 \%$ (75) were female. There was no sex significant difference.

No significant differences in the annual average of the following measures (data not shown) when the analysis of total concentration of $\mathrm{O}_{3} \mathrm{Du}$ in the studied region for the ten years of pinguecula study of prospective patients were found.

Table 1 presents the prevalence of EPCD, pinguecula and pterygium in percentages and absolute values, gender distribution and mean age $\pm \mathrm{DE}$ with their corresponding ranges of the individuals under study. The highest prevalence corresponded to pinguecula (32.1\%), followed by EPCD (28.9\%) and pterygium (13.2\%). Table 1 also shows the distribution of the distinct pathologies according to sex and age.
A significant statistical association was found between EPCD and patients' sex $(\mathrm{p} \leq 0.05)$, being it more frequent in male $(21.4 \%)$ than in female patients (7.5\%). However, no statistical differences were found between pinguecula and pterygium when men and women were compared, as well as between the ages of men and women for any of the three diseases.

The degrees of EPCD severity were determined for the 46 affected patients, being grade 1 the most frequent with 35 individuals (76.09\%), followed by 9 patients with grade $2(19.57 \%)$ and two individuals with grade 3 (4.35\%). The EPCD gradeswere significantly different between men and women $(\mathrm{p} \leq 0.05)$. We did not find differences between the ages and the distinct degrees of EPCD, although there was a tendency toward older ages in grades 2 and 3 (Table 2).

As can be observed in Table 3, the mean ages were significantly different between patients with versus without EPCD (60.2 \pm 10.8 vs. $50.9 \pm 15.8$ ). There was neither significant difference in the mean age of patients with and without pinguecula $(54.3 \pm 11.4$ vs. $53.3 \pm 15.6)$, nor in individuals affected or not with pterygium (55.4 \pm 7.9 vs. 53.3 $\pm 15.4)$.

Of the 46 individuals with EPCD, twenty-five (54.35\%) presented only this ophthalmoheliosis. Thirty-one of the 51 patients with pinguecula (62\%) only had this disease, and of the 21 individuals with
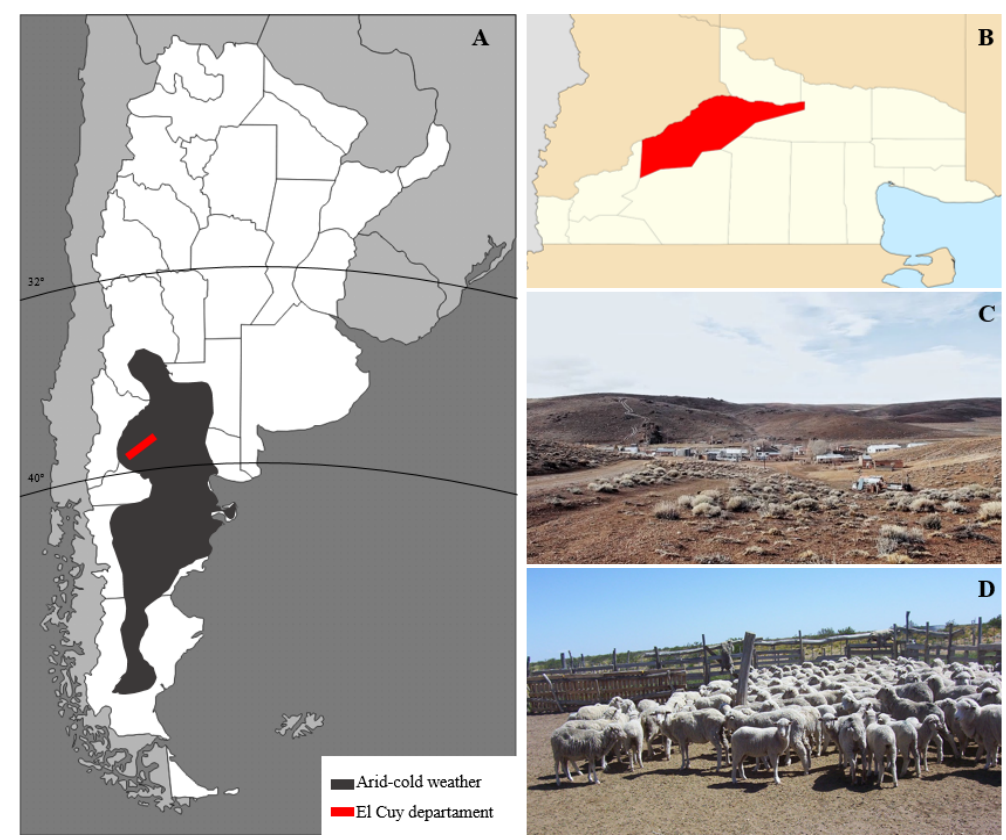

Figure 1. A) Map of the Argentine Republic indicating in red color the Department of El Cuy and in black the Patagonian area with a semi-arid-cold climate (Bwk, Köppen classification), B) Map of the province of Río Negro in light yellow color with the Department of El Cuy in red, C) Panoramic view of a small town of the Department of El Cuy, D) Main work activity of the inhabitants of the Department of El Cuy

Table 1. Prevalence of distinct pathologies and age and gender distribution

\begin{tabular}{|c|c|c|c|c|c|c|}
\hline \multirow[b]{2}{*}{ Male } & \multicolumn{2}{|c|}{$\begin{array}{c}\text { EPCD } \\
\% \text { Age }(\text { mean } \pm \text { SD) (n) (Range) }\end{array}$} & \multicolumn{2}{|c|}{$\begin{array}{c}\text { Pinguecula } \\
\% \text { Age }(\text { mean } \pm \text { SD) }(\mathrm{n}) \\
(\text { Range })\end{array}$} & \multicolumn{2}{|c|}{$\begin{array}{c}\text { Pterygium } \\
\% \text { Age }(\text { mean } \pm \text { SD) }(n) \text { (Range) }\end{array}$} \\
\hline & $21.4 \% *(34)$ & $\begin{array}{c}60.3 \pm 10.5 \\
(39-83)\end{array}$ & $\begin{array}{c}29.5 \% \\
(31)\end{array}$ & $\begin{array}{c}54.2 \pm 12.3 \\
(29-78)\end{array}$ & $\begin{array}{l}7.5 \% \\
(12)\end{array}$ & $\begin{array}{c}54.2 \pm 7.5 \\
(38-67)\end{array}$ \\
\hline Female & $7.5 \%(12)$ & $\begin{array}{c}59.9 \pm 12.1 \\
(42-79)\end{array}$ & $\begin{array}{c}12.6 \% \\
(20)\end{array}$ & $\begin{array}{c}54.5 \pm 10.3 \\
(40-77)\end{array}$ & $\begin{array}{c}5.7 \% \\
(9)\end{array}$ & $\begin{array}{c}57.0 \pm 8.7 \\
(44-71)\end{array}$ \\
\hline Total & $28.9 \%(46)$ & $\begin{array}{c}60.2 \pm 10.8 \\
(39-83)\end{array}$ & $\begin{array}{c}32.1 \% \\
(51)\end{array}$ & $\begin{array}{c}54.3 \pm 11.4 \\
(29-78)\end{array}$ & $\begin{array}{c}13.2 \% \\
(21)\end{array}$ & $\begin{array}{c}55.4 \pm 7.9 \\
(38-71)\end{array}$ \\
\hline
\end{tabular}

${ }^{*} \mathrm{p} \leq 0.05$ 
Table 2. EPCD degrees and distribution by gender and age

\begin{tabular}{|c|c|c|c|}
\hline $\begin{array}{c}\text { EPCD } \\
\%\end{array}$ & Grade 1 & Grade 2 & Grade 3 \\
$(\mathrm{n})$ & $43.24 \%$ & $10.85 \%$ & $2.38 \%$ \\
$(2)$ & $(9)$ & $2.38 \%(2) *$ \\
\hline Male: \% (n) & $28.57 \%(24) *$ & $9.52 \%(8) *$ & $0 \%(0)$ \\
\hline Female: \% (n) & $14.67 \%(11)$ & $1.33 \%(1)$ & $68.0 \pm 4.3$ \\
\hline Age: $($ mean \pm SD) & $58.3 \pm 11.25$ & $66.2 \pm 6.9$ & \\
\hline
\end{tabular}

$* \mathrm{p} \leq 0.05$

Table 3. Median ages of patients with and without EPCD with and without pinguecula and with or without pterygium

\begin{tabular}{|c|c|c|c|c|c|c|}
\hline \multirow[t]{2}{*}{ Age } & \multicolumn{2}{|c|}{$\begin{array}{c}\text { EPCD } \\
\text { Age }(\text { median } \pm \text { SD) } \\
\text { Range }\end{array}$} & \multicolumn{2}{|c|}{$\begin{array}{c}\text { Pinguecula } \\
\text { Age }(\text { median } \pm \text { SD) } \\
\text { Range }\end{array}$} & \multicolumn{2}{|c|}{$\begin{array}{c}\text { Pterygium } \\
\text { Age (median } \pm \text { SD) } \\
\text { Range }\end{array}$} \\
\hline & With & without & with & without & with & without \\
\hline Male & $\begin{array}{c}60.3 \pm 10.5 \\
(39-83)\end{array}$ & $\begin{array}{c}49.3 \pm 15.7 \\
(21-88)\end{array}$ & $\begin{array}{c}54.2 \pm 12.3 \\
(29-78)\end{array}$ & $\begin{array}{c}57.0 \pm 14.1 \\
(20-83)\end{array}$ & $\begin{array}{c}54.2 \pm 7.5 \\
(38-67)\end{array}$ & $\begin{array}{c}56.3 \pm 14.2 \\
(20-83)\end{array}$ \\
\hline Female & $\begin{array}{c}59.9 \pm 12.1 \\
(42-79)\end{array}$ & $\begin{array}{c}53.0 \pm 14.5 \\
(20-82)\end{array}$ & $\begin{array}{c}54.5 \pm 10.3 \\
(40-77)\end{array}$ & $\begin{array}{c}49.7 \pm 16.9 \\
(21-88)\end{array}$ & $\begin{array}{c}57.0 \pm 8.7 \\
(44-71)\end{array}$ & $\begin{array}{c}50.1 \pm 16.1 \\
(21-88)\end{array}$ \\
\hline Total & $\begin{array}{c}60.2 \pm 10.8^{*} \\
(39-83)\end{array}$ & $\begin{array}{c}50.9 \pm 15.2 \\
(20-88)\end{array}$ & $\begin{array}{c}54.3 \pm 11.4 \\
(29-78)\end{array}$ & $\begin{array}{c}53.3 \pm 15.6 \\
(20-88)\end{array}$ & $\begin{array}{c}55.4 \pm 7.9 \\
(38-71)\end{array}$ & $\begin{array}{c}53.3 \pm 7.9 \\
(20-88)\end{array}$ \\
\hline
\end{tabular}

$* \mathrm{p} \leq 0.05$

pterygium, only $10(47.62 \%)$ had this degeneration of the ocular surface (Table 4).

As can be observed in Table 5, significant differences in the association of EPCD with pinguecula and EPCD with pterygium were found within the group of males $(p \leq 0,05)$. In the case of a significant statistical association, pinguecula was more associated than pterygia. Additionally, there were four patients who simultaneously had pinguecula and pterygia.

The clinical records of the 15 patients that only presented pinguecula, and 8 patients with pterygium at the time of the study, were analyzed as well. They had all had these pathologies at least in the last 10 years.

As regards lifestyle of the habitants of the studied region, the main occupation of the population was breeding and sheep shearing, and in some cases, wool processing and manufacturing. The main dietary habits of these individuals included the ingestion of ovine meat two or three times a day and small amounts of milk sporadically. Vegetables and fruit were exceptional in their diet. Patients also manifested that they drank mate infusion. As for eye protection, most did not wear hats or spectacles. Forty-six patients with EPCD manifested having worked outside breeding sheep during the greater part of their live, they had not used ocular protection (hats or glasses) and had had a very restrictive diet throughout their lives.

A lipid profile was obtained for each of the two classes of glycerophospholipids: phosphatidylcholine (PC) and phosphatidylserine (PS) in corneal epithelium in three patients with EPCD in the affected and unaffected areas (control), and in conjunctival tissues of three patients with pterygium (pterygium and control conjunctiva).

For EPCD we observed a 15 -fold decrease of the concentration of total phospholipids in affected areas compared to those without alterations. The same tendency was observed when quantifying PC (4.3 times less in affected areas) and PS (25.3) separately (Figures 2A, 2B and $2 \mathrm{C}$ ).

An increase in the amount of total phospholipid concentration was detected in pterygia with respect to normal conjunctiva (16.73 and 3.04 times more in pterygium than in normal connective tissue, respectively)
(Figures 2D, 2E and 2F). The total amount of phospholipids was normalized with respect to the concentration of protein in the aqueous phase of the extraction.

\section{Discussion}

In this work we studied the prevalence of EPCD, pinguecula, and pterygium, in a particular region of the Argentine Patagonian. We found a high prevalence of EPCD (28.9\%), coincidentally with previous observations [11]. Chronic inflammation and microtrauma of the ocular surface by soil dust carried by constant windscould be risk factors for EPCD. Additionally, EPCD patients are exposed throughout life to UVR-B as they work outside in that arid and shadeless region, not wearing eye protection (sunglasses or hats). UVR-B is primarily absorbed by means of electronic transitions of the peptides connection (190-220nm) and by the aromatic motives of tryptophan, tyrosine and phenylalanine $(250-300 \mathrm{~nm})$ residue, which take the partial folding and aggregation of proteins among which there are enzymes such as aldehyde dehydrogenase (ALDH) and glutathione peroxidase,

Table 4. Individuals who presented only one ophthalmoheliosis

\begin{tabular}{|c|c|c|c|}
\hline Only one disease & $\begin{array}{c}\text { Only EPCD } \\
\%(\mathbf{n})\end{array}$ & $\begin{array}{c}\text { Only Pinguecula } \\
\text { \% (n) }\end{array}$ & $\begin{array}{c}\text { Only Pterygium } \\
\text { \% (n) }\end{array}$ \\
\hline Male & $36.96 \%(17)$ & $36 \%(18)$ & $23.81 \%(5)$ \\
\hline Female & $17.39 \%(8)$ & $26 \%(13)$ & $23.81 \%(5)$ \\
\hline Total & $54.35 \%(25)$ & $62 \%(31)$ & $47.62 \%(10)$ \\
\hline
\end{tabular}

Table 5. Association between EPCD and other ophthalmoheliosis by gender

\begin{tabular}{|c|c|c|c|}
\hline & $\begin{array}{c}\text { EPCD } \\
+ \\
\text { Pterygium } \\
\% \text { \% (n) }\end{array}$ & $\begin{array}{c}\text { EPCD } \\
+ \\
\text { Pinguecula } \\
\% \text { (n) }\end{array}$ & $\begin{array}{c}\text { EPCD } \\
+ \\
\text { Pinguecula }+ \text { Pterygium } \\
\%(n)\end{array}$ \\
\hline Male & $13.0 \%(6) *$ & $23.9 \%(11)^{*}$ & $2.2 \%(1)$ \\
\hline Female & $0 \%(0)$ & $6.5 \%(3)$ & $0 \%(0)$ \\
\hline Total & $13.0 \%(6) *$ & $30.4 \%(14) *$ & $2.2 \%(1)$ \\
\hline
\end{tabular}
$* \mathrm{p} \leq 0.05$
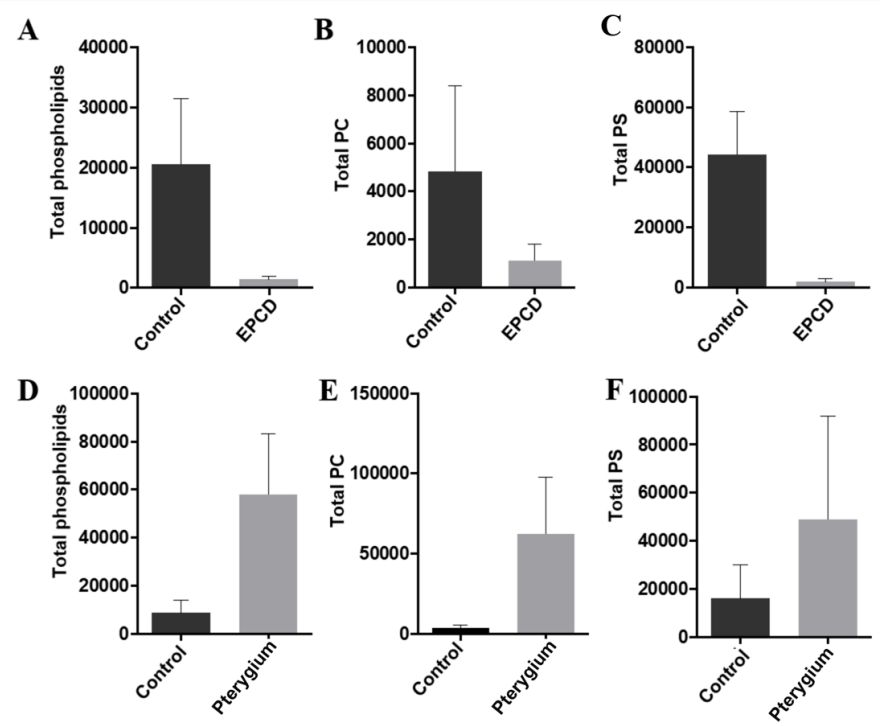

Figure 2. Concentration of phospholipids in cornea and conjunctiva of patients with EPCD and with pterygium. (A) Total phospholipids in corneal epithelium from control areas (or unaffected) and in affected areas with EPCD. (B) Concentration of PC in control zones versus affected areas with EPCD and (C) Concentration of PS in control area versus affected areas with EPCD. (D) Total phospholipids in conjunctiva control versus conjunctiva affected by pterygium. (E) Concentration of PC in control zones versus pterygium and (F) Concentration of PS in the control area versus area with pterygium. All concentrations are expressed in $\mathrm{pmol}$ (of the corresponding phospholipid/ $\mu \mathrm{g}$ of proteins) 
which play an important role to control oxidative stress [20]. As EPCD patients have a partial deficiency of ascorbate (AA) [17] (an important antioxidant in the cornea) there is less absorption of UVR-B by the AA and greater generation of ROS. These free radicals start a chain reaction that results in the oxidation of poly-unsaturated lipid of the cell membranes (lipid peroxidation) with its quantitative and qualitative lipid alterationsand generation of toxic and reactive aldehydes [21]. These molecules, in contrast to ROS, have a long life and induce more protein aggregates, which characterize the progressive corneal opacification in patients with EPCD [22].

An excessive exposure to UVR-B also seems to foster the development of pinguecula, characterized by the epithelial and squamous metaplasia that produces instability of the lachrymal film [23-24]. Pinguecula was the most frequently found ophthalmoheliosis in our study (32.1\%). Most population studies in different parts of the world show a prevalence of pinguecula ranging from $40 \%$ to $70 \%$ of the adult population $[13,25-28]$, with some exceptions like a population study in the South of India by Asokan that found a prevalence of only $11.3 \%$ [29], and as high as $90 \%$ in the city of Aqaba in Jordan [30] Pinguecula has been considered by some as the precursor or trigger of pterygium [16]. However, in our study none evolved into pterygium in the 10-year follow-up.

Prevalence rates of pterygia in population studies at world level show variation that range from $7 \%$ to $15 \%$, depending on the latitude and altitude of the region where they are studied [31-39]. Permanent exposure to sunlight (UVR-B) close to the Equator is considered as the principal causal factor of pterygium, as indicated by the facts of a very low prevalence $(0.7 \%)$ in Denmark and 60\% prevalence in Shahroud, Iran $[13,28]-$ However, low preponderances have been reported in Beijing (3\% ) [40-41], intermediate values (around 12\% ) in Hawaii [42], and the south of India [29]. Although pterygium has been reported as scant in the north and south of parallels 40 , there is a description of $5.9 \%$ pterygium prevalence in a community at 42 degrees latitude $\mathrm{N}$ of Spain [27]. The prevalence of this disease around the world has been recently reviewed by Rezvan. Our work shows a pterygium prevalence of $13.2 \%$ in a population located at the north west of Argentine Patagonia steppe (38 degrees south latitude) [43].

All these findings indicated that, although exposure to UVR-B could be a causal principal factor, it is far from being the only one. There are works that document the existence of pterygium related to certain ethnic groups (genetic predisposition) [32,44-45], viral infections [46], and to defects in genes associated with DNA repair [47]. DNA is one of the greatest targets of UVR-B induced oxidative stress, and the modified DNA can result in genetic mutations [48]. There is consensus that UVR-B causes limbal focal defects, which are the main pathogenic factors in pterygium.

Our findings of higher PC and PS in our samples of pterygium could be explained by the increase in proliferation, angiogenesis and epithelial mesenchymal transition, which is observed in this pathology. Besides, Fox et al have demonstrated that in pterygium there is an increase of autacoid12-HETE, a powerful pro-inflammatory and pro-angiogenic mediator [49]. Our investigation shows the existence of EPCD, pinguecula and pterygium south of parallel 30, outside the "pterygium belt" described by Cameron [50]. We found a greater number and degree of EPCD severity in older men, but no difference in the prevalence of pinguecula and pterygium between men and women or between ages. As far as we know, it is worth to emphasize that this is the first study of its kind at world level showing the coexistence of these three degenerative diseases of the ocular surface in a population inhabiting the Argentine Patagonia steppe.

Besides the individuals who only suffer from EPCD, or pinguecula, or pterygium, we identified patients with EPCD and pinguecula, others with EPCD and pterygium, a small number of individuals with pinguecula and pterygium and individuals with the three pathologies.

Even though there is a small cohort of pinguecula patients, the follow up of these patients for ten years showed that it is unlikely that pinguecula could be the beginning of pterygium. These diseases of the ocular surface can cause ocular discomfort, irritation, visual disturbance, and have cosmetic effects. They can also cause frustration in the affected individuals, given that there is no medical treatment available. Pinguecula is generally not treated, except for those cases which present recurrent inflammation, while the treatments of advanced cases of pterygium and EPCD, although they are different, consist of the extraction of the affected areas by surgery. As have been reviewed by Serra [51], different pterygium surgery techniques have been developed in the last decade. In cases of marked corneal opacity of patients with EPCD, penetrating or laminar queratosplasty, and the implant of an amniotic membrane have been used [52-54].

A greater knowledge of the genesis of these pathologies might contribute to preventing such potentially disabling diseases, taking into consideration that the cure is very complicated in marginal zones of the planet where there is high prevalence.

In conclusion, our investigation shows important prevalence of EPCD, pinguecula and pterygium in individuals that live in a semi deserted region of the Province of Río Negro, Argentine Patagonia. Besides those patients who only suffer from EPCD, or pinguecula, or pterygium, we identified patients with EPCD and pinguecula, others with EPCD and pterygium, a small number of individuals with pinguecula and pterygium and individuals with the three pathologies. The decrease concentration of phospholipids in EPCD affected areas could be due to lipid peroxidation, as a consequence of oxidative stress. On the other hand, higher levels of PC and PS in pterygium samples could be explained by the increase in proliferation, angiogenesis and epithelial mesenchymal transition, observed in this ocular disease. It is noteworthy that this is the first work in the world that shows coexistences between these three degenerative diseases of the ocular surface.

\section{Authorship and contribution}

María Fernanda Suarez: mass spectrometric lipidomic studies; analysis and interpretation of data; writing of the manuscript, text editing, final manuscript revision.

Nicolas Crim: ophthalmologic examination; acquisition, analysis and interpretation of data; statistical analysis, writing of the manuscript, text editing, final manuscript revision.

Leandro Correa: analysis and interpretation of data; statistical analysis; final manuscript revision.

Juan Pablo Maccio: Ophthalmic examination of patients; analysis and interpretation of data; final manuscript revision.

Erna Gertrudis Knoll: Ophthalmic examination of patients; analysis and interpretation of data; final manuscript revision.

María del Carmen Piqueras: mass spectrometric lipidomic studies; analysis and interpretation of data; text editing; final manuscript revision. 
Andrés Lisker-Cervantes: Interpretation of data; text editing and translate, final manuscript revision.

Sajoy K. Bhattacharya: Interpretation of data; text editing; final manuscript revision.

Horacio M. Serra: conception and design of the work; analysis and interpretation of data; writing of the manuscript and text editing; final manuscript critical revision and correction.

\section{Funding support}

FONCYT PICT: 2011-1846; CONICET: PIP 112-200801-01455, SECYT UNC, NIH grant P30-EY14801 and unrestricted grant from Research to Prevent Blindness to University of Miami.

\section{References}

1. Blumthaler M, Grbner J Huber M, Ambach W (1996) Measuring spectral and spatial variations of UVA and UVB sky radiance. Geophys Ret Lett 23: 547-550.

2. Sliney DH (2002) How light reaches the eye and its components. Int $J$ Toxicol 21: 501-509. [Crossref]

3. Zigman S (1993) Ocular light damage. Photochem Photobiol 57: 1060-1068. [Crossref]

4. Estey T, Piatigorsky J, Lassen N, Vasiliou V (2007) ALDH3A1: a corneal crystallin with diverse functions. Exp Eye Res 84: 3-12. [Crossref]

5. Marchetti C, Sidahmed-Adrar N, Collin F, Jore D, Gardès-Albert M, et al. (2011) Melatoninprotects PLPC liposomes and LDL towards radical induced oxidation. $J$ Pineal Res 51: 286-296. [Crossref]

6. Kau HC, Tsai CC, Lee CF, Kao SC, Hsu WM, et al. (2006) Increased oxidative DNA damage, 8-hydroxydeoxy- guanosine, in human pterygium. Eye (Lond) 20: 826-831. [Crossref]

7. Bensasson RV, Land EJ, Truscott TG (1993) Excited states and free radicals in biology and medicine: Contributions from flash photolysis and pulse radiolysis. Oxford University Press.

8. Pattison DI, Davies MJ (2006) Actions of ultraviolet light on cellular structures. EXS: 131-157. [Crossref]

9. Urrets-Zavalía JA, Knoll EG, Maccio JP, Urrets-Zavalía EA, Saad JA, et al. (2006) Climatic droplet keratopathy in the Argentine Patagonia. Am J Ophthalmol 141: 744746. [Crossref]

10. Suarez MF, Correa L, Crim N, Espósito E, Monti R, et al. (2015) Climatic droplet keratopathy in Argentina: involvement of environmental agents in its genesis which would open the prospect for new therapeutic interventions. Biomed Res Int 527835.

11. Serra HM, Holopainen JM, Beuerman R, et al. (2015) Climatic droplet keratopathy: an old disease in new clothes. Acta Ophthalmol 93: 496-504. [Crossref]

12. Cardenas-Cantu E, Zavala J, Valenzuela J, Valdez-Garcia JE (2016) Molecular Basis of Pterygium Development. Semin Ophthalmol 31: 567-583. [Crossref]

13. Norn MS (1979) Prevalence of pinguecula in Greenland and in Copenhagen, and its relation to pterygium and spheroid degeneration. Acta Ophthalmol (Copenh) 57: 96105. [Crossref]

14. ForsiuS H, Eriksson A (1963) [The incidence of pinguecuia and pterygium in indoor and outdoor workers]. Klin Monbl Augenheilkd 142: 1021-1030. [Crossref]

15. Kim TH, Chun YS, Kim JC (2013) The pathologic characteristics of pingueculae on autofluorescence images. Korean J Ophthalmol 27: 416-420. [Crossref]

16. Hilgers JH (1960) Pterygium: its incidence, heredity and etiology. Am J Ophthalmol 50: 635-644. [Crossref]

17. Suárez MF Correa L, Crim N, Espósito E, Monti R, et al. (2015) Climatic droplet keratopathy in Argentina: involvement of environmental agents in its genesis which would open the prospect for new therapeutic interventions. BioMed Research International.

18. Bligh EG, Dyer WJ (1959) A rapid method of total lipid extraction and purification. Can J Biochem Physiol 37: 911-917. [Crossref]

19. Suarez MF, Piqueras MC, Correa L, Esposito E, Barros MF, etc. (2017) Phospholipidomic studies in human cornea from climatic droplet keratopathy. $J$ Cell Biochem. [Crossref]
20. Serra HM, Suarez MF, Esposito E, Urrets-Zavalía JA (2014) Vitamin C functions in the crnea: Ultra-structural features in ascorbate deficiency. In: Preedy VR (ed.). The handbook of nutrition, diet and the eye. London, UK: Elsevier 31: 311-320.

21. Marchitti SA, Chen Y, Thompson DC, Vasiliou V (2011) Ultraviolet radiation: cellular antioxidant response and the role of ocular aldehyde dehydrogenase enzymes. Eye Contact Lens 37: 206-213. [Crossref]

22. Serra HM, Suárez MF, Urrets-Zavalía JA (2017) Environmental proteinaceous corneal degeneration: A rare disease. In: "Rare diseases", URL: http://www.avidscience.com/ book/rare-diseases/.

23. Yam JC, Kwok AK (2014) Ultraviolet light and ocular diseases. Int Ophthalmol 34 383-400. [Crossref]

24. Dong N1, Li W, Lin H, Wu H, Li C, et al. (2009) Abnormal Epithelial Differentiation and Tear Film Alteration in Pinguecula. Invest Ophthalmol Vis Sci 50: 2710-2715. [Crossref]

25. Panchapakesan J, Hourihan F, Mitchell P (1998) Prevalence of pterygium and pinguecula: the Blue Mountains Eye Study. Aust N Z J Ophthalmol 26 Suppl 1: S2-5. [Crossref]

26. Fotouhi A, Hashemi H, Khabazkhoob M, Mohammad K (2009) Prevalence and risk factors of pterygium and pinguecula: the Tehran Eye Study. Eye (Lond) 23: 1125-1129. [Crossref]

27. Viso E, Gude F, Rodríguez-Ares MT (2011) Prevalence of pinguecula and pterygium in a general population in Spain. Eye (Lond) 25: 350-357. [Crossref]

28. Rezvan F, Hashemi H, Emamian MH, Kheirkhah A, Shariati M, et al. (2012) The prevalence and determinants of pterygium and pinguecula in an urban population in Shahroud, Iran. Acta Med Iran 50: 689-696. [Crossref]

29. Asokan R, Venkatasubbu RS, Velumuri L, Lingam V, George R (2012) Prevalence and associated factors for pterygium and pinguecula in a South Indian population. Ophthalmic PhysiolOpt 32: 39-44. [Crossref]

30. Norn MS (1982) Spheroid degeneration, pinguecula, and pterygium among Arabs in the Red Sea territory, Jordan. Acta Ophthalmol (Copenh) 60: 949-954. [Crossref]

31. Cajucom-Uy H, Tong L, Wong TY, Tay WT, Saw SM (2010) The prevalence of and risk factors for pterygium in an urban Malay population: the Singapore Malay Eye Study (SiMES). Br J Ophthalmol 94: 977-981. [Crossref]

32. Huang TL, Hsu SY, Tsai RK, Sheu MM (2010) Etiology of ocular diseases in elderly Amis aborigines in Eastern Taiwan (The Amis Eye Study). Jpn J Ophthalmol 54: 266271. [Crossref]

33. Wu K, He M, Xu J (1999) The epidemiological characteristic of pterygium in middle aged and the elderly in Doumen County. J Clin Ophthalmol 7: 17-18.

34. Singh MM, Murthy GV, Venkatraman R, Rao SP, Nayar S (1997) A study of ocular morbidity among elderly population in a rural area of central India. Indian J Ophthalmol 45: 61-65.

35. Gazzard G, Saw SM, Farook M, Koh D, Widjaja D, et al. (2002) Pterygium in Indonesia: prevalence, severity and risk factors. Br J Ophthalmol 86: 1341-1346. [Crossref]

36. Wong TY, Foster PJ, Johnson GJ, Seah SK, Tan DT (2001) The prevalence and risk factors for pterygium in an adult Chinese population in Singapore: the Tanjong Pagar survey. Am J Ophthalmol 131: 176-183. [Crossref]

37. Hussain A, Awan H, Khan MD (2004) Prevalence of nonvision-impairing conditions in a village in Chakwal district, Punjab, Pakistan. Ophthalmic Epidemiol 11: 413-426. [Crossref]

38. Lu J, Wang Z, Lu P, Chen X, Zhang W, et al. (2009) Pterygium in an aged Mongolian population: a population-based study in China. Eye (Lond) 23: 421-427. [Crossref]

39. Lu P, Chen X, Kang Y, Ke L, Wei X, et al. (2007) Pterygium in Tibetans: a populationbased study in China. Clin Exp Ophthalmol 35: 828-833. [Crossref]

40. Liang QF, Xu L, Jin XY, You QS, Yang XH, et al. (2010) Epidemiology of pterygium in aged rural population of Beijing, China. Chin Med $J$ (Engl) 123: 1699-1701. [Crossref]

41. Ma K, Xu L, Jie Y, Jonas JB (2007) Prevalence of and factors associated with pterygium in adult Chinese: the Beijing Eye Study. Cornea 26: 1184-1186. [Crossref]

42. Lin AD, Miles K, Brinks MV (2016) Prevalence of Pterygia in Hawaii: examining cumulative surfing ours as a risk factor. Ophthalmic Epidemiol 23: 264-268. 
43. Rezvan F, Khabazkhoob M, Hooshmand E, Yekta A, Saatchi M, et al. (2018) Prevalence and risk factors of pterygium: a systematic review and meta-analysis. Surv Ophthalmol 63: 719-735. [Crossref]

44. Shiroma H, Higa A, Sawaguchi S, Iwase A, Tomidokoro A, et al. (2009) Prevalence and risk factors of pterygium in a southwestern island of Japan: the Kumejima Study. Am J Ophthalmol 148: 766-771. [Crossref]

45. West S, Muñoz B (2009) Prevalence of pterygium in Latinos: Proyecto VER. $B r J$ Ophthalmol 93: 1287-1290. [Crossref]

46. Detorakis ET, Spandidos DA (2009) Pathogenetic mechanisms and treatment options for ophthalmic pterygium: trends and perspectives (Review). Int J Mol Med 23: 439447. [Crossref]

47. Liu T, Liu Y, Xie L, He X, Bai J (2013) Progress in the pathogenesis of pterygium. Curr Eye Res 38: 1191-1197. [Crossref]

48. Cadet J, Douki T, Gasparutto D, Ravanat JL (2003) Oxidative damage to DNA: formation, measurement and biochemical features. Mutat Res 531: 5-23.
49. Fox T, Gotlinger KH, Dunn MW, Lee OL, Milman T, et al. (2013) Dysregulated heme oxygenase-ferritin system in pterygium pathogenesis. Cornea 32: 1276-1282. [Crossref]

50. Cameron ME (1965) Pterygium throughout the World. Springfield, Charles C. Thomas

51. Serra HM, Suarez MF, Maccio JP, Esposito E, Urrets-Zavalía JA (2017) Pterygium: A Complex and Multifactorial Ocular Surface Disease. A Review on its Pathogenic Aspects. In: "Rare diseases", ISBN: 978-93-86337-80-1. URL: http://www.avidscience. $\mathrm{com} /$ book/rare-diseases

52. Saini JS1, Jain AK, Sukhija J, Saroha V (2003) Indications and outcome of optical partial thickness lamellar keratoplasty. Cornea 22: 111-113. [Crossref]

53. Al-Towerki AE (2007) Superficial keratectomy using microkeratome for treatment of irregular climatic droplet keratopathy (free flap). Graefe's Arch Clin Exp Ophthalmol 245:183-184. [Crossref]

54. Rao A, Sridhar U, Gupta AK (2008) Amniotic membrane transplant with superficial keratectomy in superficial corneal degenerations: efficacy in a rural population of north India. Indian J Ophthalmol 56: 297-302. [Crossref]

Copyright: (C2019 Suárez MF. This is an open-access article distributed under the terms of the Creative Commons Attribution License, which permits unrestricted use, distribution, and reproduction in any medium, provided the original author and source are credited. 